\title{
Blood Products Broker, Distributor, Warehouse
}

National Cancer Institute

\section{Source}

National Cancer Institute. Blood Products Broker, Distributor, Warehouse. NCI

Thesaurus. Code C133300.

A broker, distributor, or warehouse that stores and redistributes source material for further manufacture, such as recovered plasma, source plasma, and whole blood, red blood cells, or platelets for diagnostic product use. 